\title{
An Innovative Vegetative Propagation System for Large-scale Production of Globe Artichoke Transplants. Part II. Propagation System Validation
}

\author{
Mariateresa Cardarelli, Youssef Rouphael, Francesco Saccardo, \\ and Giuseppe Colla
}

AdDitional INDEX wORDs. offshoot, validation, propagation, globe artichoke, cost

SUMMARY. Research was conducted at the University of Tuscia (central Italy) to validate the propagation system for globe artichoke (Cynara cardunculus var. scolymus) described in a previous paper for a 1 -year production cycle. The resulting globe artichoke plants were used in a 2 -year field trial to investigate the field response of plantlets obtained with our propagation technique in comparison with plantlets produced by in vitro propagation and by offshoots harvested in commercial fields. The total number of artichoke plantlets obtained with our propagation system was 62.7 plantlets $/ \mathrm{m}^{2}$ per year. In the first year, the globe artichoke production (bud number and fresh bud weight) was higher in plants obtained with our propagation system and by micropropagation than in those obtained from offshoots harvested in commercial fields. The production cost of plantlets obtained with our propagation technique was $52 \%$ lower than those of the micropropagated plantlets. This could lead to a significant reduction of production costs for artichoke growers, while preserving the advantages of in vitro propagation (disease-free plants and plant uniformity).

$\mathrm{G}$ lobe artichoke usually is vegetatively propagated by offshoots harvested in commercial fields at the end of the production cycle. This method often causes physiological, pathological, and economic disadvantages (Basnisky and Zohary, 1987; Calabrese et al., 2000). Micropropagation has solved many of these problems. However, in vitro propagation is expensive, and efficient micropropagation protocols are only available for a few cultivars. In a previous paper (Cardarelli et al., 2005), we set up a new propagation system for the large-scale production of globe artichoke transplants. The purpose of the current study was to validate our propagation technique carried out on a 1-year production cycle. The resulting plants were used in a 2 -year field trial to investigate the field response of plantlets obtained with our propagation system in comparison with plantlets produced by in vitro propagation and by offshoots harvested in commercial

Università della Tuscia, Dipartimento di Produzione Vegetale, via S. Camillo del Lellis snc, 01100 Viterbo, Italy; e-mail address: giucolla@unitus.it

Acknowledgments. This study was supported by the Italian Ministry of Agricultural Policy under the national research project "Artichoke." This support is gratefully acknowledged. fields. In addition, the production cost of plantlets obtained with our propagation system was compared with those of micropropagated plantlets.

\section{Materials and methods}

Expт. 1. Pathogen-free micropropagated plantlets of 'C3' artichoke (Vitroplant, Cesena, Italy) were transplanted into 20 -cm-diameter pots filled with pumice (particle diameter from 1 to $3 \mathrm{~mm}$ ) on 17 Aug. 2001. Stock plants were placed at a plant density of 5.1 plants $/ \mathrm{m}^{2}$ in a polyethylenecovered greenhouse equipped with insect-proof nets on the vent openings to prevent plant virus vectors [e.g., aphids (Brachycaudus cardui, Myzus persicae, Protrama radicum)] from entering the greenhouse. The cultural practices were the same as those reported in a previous paper (Cardarelli et al., 2005). The stock plants were grown until June 2002 and during the growing period three production cycles of offshoots were forced (Table 1). In each production cycle, 6-benzylamino purine (BA) was applied to stock plants at a concentration of $200 \mathrm{mg} \cdot \mathrm{L}^{-1}$. Offshoots were continuously harvested when they reached four to five leaves (>30 g), leaving the last well-formed offshoot, which was used to regrow the stock plant. Harvested offshoots were counted, trimmed (removing the upper half of the leaves), and immersed for $3 \mathrm{~min}$ in a watery solution containing $1 \mathrm{~g} \cdot \mathrm{L}^{-1}$ carbendazim (Bavistin; Basf Agro, Milano, Italy). Before rooting, cuttings from the I and II production cycles were cold-stored in plastic bags at $2 \pm 0.5^{\circ} \mathrm{C}$, and $90 \pm 5 \%$ relative humidity for approximately 180 to $75 \mathrm{~d}$, respectively. In June, cuttings from the I, II, and III production cycles were rooted in separate individual benches (one bench for the cuttings of the same production cycle) filled with commercial potting soil (Metro-mix 360; W.R. Grace and Co., Cambridge, Mass. ) and placed in high humidity tents. After $30 \mathrm{~d}$, the number of rooted cuttings was counted.

Eхрт. 2. A 2-year field trial was conducted on sandy-loam soil at the Viterbo experimental farm, central Italy (lat. $42^{\circ} 25^{\prime} \mathrm{N}$, long. $12^{\circ} 08^{\prime} \mathrm{E}$ ) to evaluate the effects of the plantlet production system on the yield and quality of the artichokes. The treatments were: 1) plantlets obtained from cold-stored cuttings (Expt. 1);2) plantlets obtained from cuttings that were not cold-stored (Expt. 1); 3) plantlets obtained from apparently healthy offshoots (without visual symptoms of disease) harvested from commercial fields; and 4) micropropagated plantlets. The treatments

\begin{tabular}{llll}
\hline $\begin{array}{l}\text { Units } \\
\begin{array}{l}\text { To convert U.S. to SI, } \\
\text { multiply by }\end{array}\end{array}$ & U.S. unit & SI unit & $\begin{array}{l}\text { To convert SI to U.S., } \\
\text { multiply by }\end{array}$ \\
\hline 0.4047 & $\mathrm{acre}(\mathrm{s})$ & $\mathrm{ha}$ & 2.4711 \\
0.3048 & $\mathrm{ft}$ & $\mathrm{m}$ & 3.2808 \\
0.0929 & $\mathrm{ft}^{2}$ & $\mathrm{~m}^{2}$ & 10.7639 \\
0.0283 & $\mathrm{ft}^{3}$ & $\mathrm{~m}^{3}$ & 35.3147 \\
2.5400 & inch(es $)$ & $\mathrm{cm}$ & 0.3937 \\
25.4000 & inch(es & $\mathrm{mm}$ & 0.0394 \\
1.1209 & $\mathrm{lb} / \mathrm{acre}$ & $\mathrm{kg} \cdot \mathrm{ha}^{-1}$ & 0.8922 \\
28.3495 & $\mathrm{Oz}$ & $\mathrm{g}$ & 0.0353 \\
70.0532 & $\mathrm{Oz} / \mathrm{acre}$ & $\mathrm{g} \cdot \mathrm{ha}{ }^{-1}$ & 0.0143 \\
7.4892 & $\mathrm{Oz} / \mathrm{gal}$ & $\mathrm{g} \cdot \mathrm{L}^{-1}$ & 0.1335 \\
1 & $\mathrm{ppm}$ & $\mathrm{mg} \cdot \mathrm{L}^{-1}$ & 1 \\
$\left({ }^{\circ} \mathrm{F}-32\right) \div 1.8$ & ${ }^{\circ} \mathrm{F}$ & ${ }^{\circ} \mathrm{C}$ & $\left(1.8 \times{ }^{\circ} \mathrm{C}\right)+32$
\end{tabular}


Table 1. Basic information on the globe artichoke propagation system in 2001-02. Date

Operation
17 Aug. 2001

10 Oct. 2001

17 Oct. 2001

15 Nov.-17 Dec. 2001

17 Dec. 2001

22 Jan. 2002

29 Jan. 2002

1 Mar.-1 Apr. 2002

1 Apr. 2002

30 Apr. 2002

7 May 2002

31 May-24 June 2002

31 May-24 June 2002
I production cycle

Micropropagated plantlets transplanted

Stock plants foliar-sprayed with 6-benzylamino purine (BA)

Stock plants cut back

Offshoots harvested and cold-stored

Stock plants re-growth from the last well-formed offshoot Stock plants foliar-sprayed with BA

Stock plants cut back

Offshoots harvested and cold-stored

III production cycle

Stock plants re-growth from the last well-formed offshoot Stock plants foliar-sprayed with BA

Stock plants cut back

Offshoots harvested

Rooting of cuttings which have been cold-stored (I and II cycles) and harvested from the third cycle

\section{II production cycle}

were arranged in a randomized complete-block design with three replicates. Each plot consisted of 30 plants. Plantlets were transplanted on 22 Aug. 2002 in single rows of plants $1.1 \mathrm{~m}$ apart (8264 plants/ha). Fertilizers (diammonium phosphate and sulfate of potash) were preplant spread and disked at the following rates: $54 \mathrm{~kg} \cdot \mathrm{ha}^{-1}$ of nitrogen, $61 \mathrm{~kg} \cdot \mathrm{ha}^{-1}$ of phosphorus, and $130 \mathrm{~kg} \cdot \mathrm{ha}^{-1}$ of potassium. Plants were side-dressed with $100 \mathrm{~kg} \cdot \mathrm{ha}^{-1}$ of nitrogen (ammonium nitrate) on 15 Dec. 2002 and on 17 Dec. 2003. Sidedress was applied in bands $30 \mathrm{~cm}$ to either side of the plants and $10 \mathrm{~cm}$ deep. Plots were sprinkler-irrigated "as needed" by visually monitoring the water status of the crop and soil. Weeds were controlled with $4 \mathrm{~L} \cdot \mathrm{ha}^{-1}$ of pendimethalin (Stomp 330E; Basf Agro) at planting and mechanical and hand hoeing during both growing seasons. Slugs were controlled by methiocarb (Mesurol N-Esca; Bayer CropScience, Milano, Italy) at the rate of $160 \mathrm{~g} \cdot \mathrm{ha}^{-1}$, while powdery mildew was controlled by three sulfur applications (Zolfo Bagnabile; Bayer CropScience) at the rate of $1.6 \mathrm{~g} \cdot \mathrm{L}^{-1}$. The artichoke buds were hand-harvested from the center 12 plants in each replication when the buds achieved maximum size, but before the bracts began to spread open. In 2003, the harvest period started on 14 Feb. and ended on 18 Apr., while in 2004, the growing season harvest started on $20 \mathrm{Feb}$. and ended on 29 Apr. The fresh weight and number of buds were determined.
Statistical analysis. All data were statistically analyzed by analysis of variance using SPSS (version 10 for Windows; SPSS, Inc., Chicago). Duncan's multiple range test was performed at $P \leq 0.05$ on each of the significant variables measured.

\section{Results and discussion}

The total number of cuttings per stock plant obtained in Expt. 1 decreased over the three production cycles with a higher number observed in the first cycle (7.2 cuttings/stock plant) followed by those recorded in the second and third cycles (6.1 and 4.3 cuttings/stock plant, respectively).

The percentage of rotten cuttings was lower in cuttings from the II production cycle $(5 \%)$ in comparison with those obtained in the I production cycle $(14 \%)$. This is similar to results we observed in a previous experiment in which the number of rotten cuttings increased with increased cold storage time (Cardarelli et al., 2005). Moreover, the rooting percentage was lower in cuttings of the I cycle (61\%) than in those of the II and III cycles ( $82 \%$ and $88 \%$, respectively). The total number of artichoke plantlets obtained with our propagation system was 62.7 plantlets/ $\mathrm{m}^{2}$ peryear. In Expt. 2, globe artichoke plants obtained with our propagation technique and with micropropagation produced significantly more buds (secondary, tertiary, and total) than those obtained with offshoots harvested in commercial fields (Table 2). The average fresh weight of buds was higher in plants obtained with our propagation technique and micropropagation than in those obtained with offshoots harvested in commercial fields (Table $2)$. No significant differences were observed in the treatments with regards to the number of offshoots produced per plant (average $=12$ offshoots $/$ plant , indicating that there were no residual effects of the previous applications of BA to the stock plants. This is very important because of the high operational cost of removing offshoots in the field.

In 2004, no significant differences were observed between treatments with regards to the fresh weight and number of buds. The average bud number of the first, second, third order, and the total were $1.0,3.2,4.4$, and 8.7 buds/plant, respectively. The average fresh bud weight of the first, second, and third order were 280.3 , 193.2 , and $120.7 \mathrm{~g}$, respectively.

To summarize, we can conclude that growing artichokes from plantlets obtained with our propagation technique is a valid alternative to micropropagation for the Romanesco type of globe artichoke because of the similarities in plant performance. In addition,
Table 2. Effect of propagation technique on primary, secondary, tertiary, and total bud number and fresh weight of globe artichokes during 2002-03 growing season (Expt. 2). Values are the mean of three replicate samples.

\begin{tabular}{|c|c|c|c|c|c|c|c|}
\hline \multirow[b]{3}{*}{ Treatment $^{\mathrm{y}}$} & \multicolumn{7}{|c|}{ Buds } \\
\hline & \multicolumn{4}{|c|}{ No. (no./plant) } & \multicolumn{3}{|c|}{ Mean wt (g/plant) ${ }^{\mathrm{z}}$} \\
\hline & Primary & Secondary & Tertiary & Total & Primary & Secondary & Tertiary \\
\hline $\mathrm{Cl}$ & $1.0 \mathrm{a}^{\mathrm{x}}$ & $3.0 \mathrm{a}$ & $4.0 \mathrm{a}$ & $8.1 \mathrm{a}$ & $245.0 \mathrm{a}$ & $180.7 \mathrm{a}$ & $121.7 \mathrm{a}$ \\
\hline $\mathrm{C} 2$ & $1.0 \mathrm{a}$ & $2.8 \mathrm{a}$ & $4.2 \mathrm{a}$ & $8.0 \mathrm{a}$ & $240.3 \mathrm{a}$ & $175.9 \mathrm{a}$ & $112.6 \mathrm{a}$ \\
\hline $\mathrm{T}$ & $1.0 \mathrm{a}$ & $2.2 \mathrm{~b}$ & $3.3 \mathrm{~b}$ & $6.4 \mathrm{~b}$ & $230.1 \mathrm{~b}$ & $151.3 \mathrm{~b}$ & $114.9 \mathrm{a}$ \\
\hline M & $1.0 \mathrm{a}$ & $3.1 \mathrm{a}$ & $4.3 \mathrm{a}$ & $8.3 \mathrm{a}$ & $250.2 \mathrm{a}$ & $183.5 \mathrm{a}$ & $120.1 \mathrm{a}$ \\
\hline
\end{tabular}

${ }^{\mathrm{z}} \mathrm{lg}=0.0353 \mathrm{oz}$

${ }^{\mathrm{y}} \mathrm{Cl}=$ plantlets obtained by cold stored cuttings of the I and II production cycle; $\mathrm{C} 2$ = plantlets obtained by cuttings of III production cycle; $\mathrm{T}=$ plantlets obtained by offshoots harvested from commercial field; $M=\mathrm{mi}-$ cropropagated plantlets.

xIn each column, values followed by the same letter do not differ significantly at $P \leq 0.05$. 
Table 3. Production cost of 1 ha $(2.47$ acres $)$ using the globe artichoke transplant production system. ${ }^{\mathrm{z}}$

\begin{tabular}{|c|c|c|}
\hline$\underline{\text { Item }}$ & Description & $\begin{array}{c}\text { Total cost } \\
(\$ / \text { transplant }) \\
\end{array}$ \\
\hline Fixed expenses ${ }^{y}$ & $\begin{array}{l}\text { Depreciation, repairs and insurance of fixed } \\
\text { investments (e.g., greenhouse, fertigation } \\
\text { system, cold storage, building) }\end{array}$ & 0.10 \\
\hline $\begin{array}{l}\text { Nonlabor } \\
\text { variable expenses }\end{array}$ & $\begin{array}{l}\text { Transplants, substrate, fertilizers, pesticides, } \\
\text { hormones, plastic bags, styrofoam trays, } \\
\text { electricity, oil }\end{array}$ & 0.20 \\
\hline Labor expenses ${ }^{x}$ & $\begin{array}{l}\text { Maintenance, transplanting, spraying, } \\
\text { cutting, and harvesting }\end{array}$ & 0.10 \\
\hline Interest expenses ${ }^{w}$ & Fixed and variable expenses & 0.04 \\
\hline \multicolumn{2}{|c|}{ Total fixed and variable expenses including interest } & 0.44 \\
\hline \multicolumn{3}{|c|}{$\begin{array}{l}{ }^{2} \text { Calculations based on } 1 \text { year with } 0.6 \mathrm{ha}(1.48 \text { acre }) \text { of greenhouse for growing stock plants, } 0.3 \mathrm{ha}(0.74 \mathrm{acre}) \\
\text { of greenhouse for offshoot rooting, } 100 \mathrm{~m}^{3}\left(3531.5 \mathrm{ft}^{3}\right) \text { of cold storage, and } 100 \mathrm{~m}^{2}\left(1076.4 \mathrm{ft}^{2}\right) \text { of building. } \\
\text { y Input prices were obtained from local greenhouse suppliers and building material suppliers. } \\
\text { x National nursery industries were consulted to obtained information regarding the operating costs associated } \\
\text { with propagation. } \\
\text { "Artichoke transplant charged a } 10 \% \text { rate of interest on capital. }\end{array}$} \\
\hline
\end{tabular}

the production costs of plantlets obtained with our propagation technique are significantly lower (Table 3 ) than those of micropropagated plantlets [ \$0.9 per transplant; this cost was provided by national commercial companies that produce around 1 million artichoke transplants per year], which could lead to a significant reduction of the production cost for artichoke growers. Our propagation technique may also be applied to early cultivars, while in vitro propagation mainly leads to late-ripening plants with more deeply divided leaves. The frequency of this occurrence increased linearly with the number of subcultures, sometimes reaching 100\% after 20 subcultures (Pécaut and Martin, 1993). In order to produce healthy plants from early cultivars, the late-ripening plants must be discarded and an accurate selection of micropropagated stock plants should be used. Finally, our propagation technique can be used in breeding programs to obtain, quickly and easily, a large number of plants per inbred line, which is a basic requirement for producing a large quantity of hybrid seed.

\section{Literature cited}

Basnizki, Y. and D. Zohary. 1987. A seed-planted cultivar of globe artichoke. HortScience 22:678-679.

Calabrese, N., A. Elia, and V.V. Bianco. 2000. Epoca di raccolta e caratteristiche qualitative di capolini di carciofo (Cynara scolymus L.) fresco e surgelato. Rivista di Agronomia 24:192-196.

Cardarelli M., Y. Rouphael, F. Saccardo, and G. Colla. 2005. An innovative vegetative propagation system for large-scale production of globe artichoke transplants. Part I. Propagation system set up. HortTechnology 15(4):812-816. 